\title{
HELPING STUDENTS WRITE NARRATIVE TEXTS \\ USING SMS (STORY MODIFICATION STRATEGY)
}

\author{
Bambang Yulianto \\ ybambang70@yahoo.com
}

SMAN 1 KEDIRI

\begin{abstract}
One of the problems faced by students in writing a narrative text (story) is that they have no ideas to develop into a full story. They usually spend so much time to think of what to write about that they finally run out of time to complete the task. Meanwhile, there is a fact that stories in movies are sometimes derived from fairy tales the setting of time and place of which have been made different. This has given me inspiration that students do not have to make a completely new story in order to write a narrative text. As students are familiar with tales, legends, or fables, what they need is only to make some modifications to the existing stories they already know. In other words, in order to be able to write a new story they actually only need to "cook" the "ingredients" they have in mind. Thus, there is no more reason for them not to write a story because of having no ideas to write. This paper will give a model of helping students using the strategy called SMS or Story Modification Strategy.
\end{abstract}

Key words: narrative text, story modification strategy, writing.

\section{Introduction}

Teaching and learning narrative text has been intensified since the 2004 curriculum in which the Genre-Based Approach is applied. This approach includes the teaching of transactional conversations, interpersonal conversations, short functional texts, monologues and essays for certain genres. Senior high school students study procedure, report, news item, 
narrative, discussion, explanation, exposition, and review texts, while junior high school students study procedure, descriptive, recount, narrative, and report texts. Narrative text is given in both junior and senior high school (Depdiknas, 2004). Therefore, in this basic competence, teachers may have adequate time to help the students to be competent in listening to a narrative text, speaking about it, reading it with comprehension, and create (compose) his own story.

However, in practice, the process of teaching narrative text is not running well. My problem came up when I was teaching writing narrative text to my eleventh grader students. The specific problem faced by most of the students was the difficulty to get ideas of what to write to create an interesting story. I assumed that students already had ability to write their own narrative texts. Unfortunately, most of them just wasted their time thinking of what to write about. Some students did write, but they only rewrote the stories they remembered.

I then interviewed some students who later explained that their previous teachers never told them how to write narrative texts. Meanwhile other students admitted that their teacher taught them how, but then the teacher did not follow the writing process done by the students. Thus the writing strategy was the problem.

Many teachers have problems in teaching writing. There are some ways to solve this problem. Some teachers use picture or potograph as the media to help student to write recount text, such as Lutfiyah (2009). She used potographs to improve her students in writing narrative text. This media successfully helped students to generate ideas.

\section{Literature Review}

This paper aims to report the results of a narrative writing project done by students of XII Social 1, SMAN 1 Kediri using a strategy called SMS or Story Modification Strategy. This project was done to help students write narrative texts. As suggested by Yulianto (2013), 
"low achieving students must be taught L2 writing strategies explicitly", this project is relevant to provide the students a solution to their problem in completing the writing task, while for good students, this will be good to provide an alternative strategy for themselves.

This strategy is inspired by the events in the world of literature, especially narrative. As the name implies, this strategy is making modifications to the existing stories. This strategy is inspired by the facts that stories can be made different by changing the setting of time, setting of place, characters, or the plots. In real life this is acceptable. Let's take the story of "Cinderella" for example. The story that has French, Italian, dan, Russia versions (Wikipedia, 2016) has been made different in movies. It has been reproduced in different settings, plots, and characters such as A Cinderella Story. This fact leads to an inspiration in teaching writing narrative text: Why not assign students to make modifications to a text they already know to make up a new one?

To my experience, this strategy is easy to apply. Students simply need to make some modifications to the story; the setting of place, setting of time, the characters, and the plot, partly or wholly. They can change the stories they already have in their memory. We believe that they know stories from other countries like Beauty and the Beast, Snow White, Robin Hood, or Little Red Riding Hood, or the local ones like Malin Kundang, The Rabbit and The Croccodiles, Timun Emas, etc. They also know movie stories like Harry Potter, Lord of the Ring, or $O z$ The Great and Powerful. What they need is only to be skillful in using it and teacher's guidance related to the language problems. In short, just like cooking, students already have the ingredients, what they need is a skill to cook them to make a good food.

\section{Method}

Based on the background above, this paper aims to investigate how the story modification strategy can help them write a narrative text. In order to provide the answer to 
the question, three instruments were used; observation, interview, and product analysis. Observation was done during the writing process in the classroom especially to see how they were completing the writing task using the strategy. During the writing process, I did the interview to find out how they liked the strategy. Product analysis was done during and after the process. During the process, the progress writing from their rough draft to full texts were analyzed, given feedbacks, and scored.

The participants of the project were students of Year XII students of Social Program of SMAN 1 Kediri of the Academic Year 2014/2015. They consisted of 12 females and 10 males.

The project was done in four meetings in the first semester of Academic Year 2014/2015. The stages of the project are as follows;

1) Making the lesson plan. Since the project was done as regular classroom activities, to guide the steps of the implementation, well-designed lesson plan was prepared (see Appendix 1)

2) Explaining the procedure of the strategy to students. This is important as clear explanation would avoid misunderstanding and misleading among the students.

3) Implementing the strategy. The implementation is the core of the project. It consisted of four meetings. In this stage, the role of the teacher was very important to motivate, guide, help find out students' writing problems, and give feedbacks

4) Evaluating the process and products of the project. During the process, students' works from making the rough draft to the complete texts were always observed and given feedbacks so that they produced interesting stories.

5) Publishing the texts. When the texts were done, the students texts were then compiled into a book and sent to the library. 


\section{Procedure of the Strategy}

Though the main step in the strategy is modification, the procedure was divided into three common steps;

1) pre-writing, consisting of motivating, modelling, and simplifying,

2) whilst-writing; modifying, drafting, and revising/editing,

3) post-writing; publishing.

\section{Pre-writing}

a. Motivating

Since not every student like writing, especially writing narrative texts, giving motivation is very essential in order to succeed in the writing class. Motivation could be given in any form, but in this project I prefered to show them the importance of having skills in writing stories by presenting succesful writers like Andrea Hirata wih his Laskar Pelangi or JK Rowling with her Harry Potter. I chose them as they are good examples of popular writers who are commercially successful. Also, I reinforce to enjoy the writing activity as their writing products would be put in the school library. Students were also informed that they could express feelings and retelling experiences in their stories (Brown, 1997: 400).

b. Modelling

In this step, the procedure of the strategy was explained. I asked the students to mention all stories they already knew. They could be in the forms of fables, legends, myths, fairy tales, novel stories, or even movies. I chose two stories entitled The Rabbit's Revenge and Charm of Charity. The two titles were available in their hand out book (Arini \& Kurniawati, 2014) and had just been discussed in reading comprehension activities.

c. Simplifying 
Simplifying means extracting the outline of an existing story, just like cutting the leaves off a tree in order to see the shape of the tree. Let's see the following samples of simplificactions. There are two levels of simplification. In the first simplification, the original text was summarized into 8 sentences. The eight sentences cover the orientation, complication, resolution, and resolution. This summary is then simplified again according to its plot, and settings of time and place. See the simplifications of the the story below.

\section{Example:}

\section{Charm Of Charity}

A poor young man was helpless, homeless and hopeless. He lost his job and had no one to help him. Depressed and dejected, he decided to commit suicide. He collected all the coins he had with him and bought from a shop a ripe banana wrapped in an old newspaper. He opened the packet and started to eat his last food when an old beggar approached him. With trembling lips, the beggar told him that he has not had anything to eat for several days and was too weak to walk. The young man felt pity and gave the banana to the beggar. He ate it with great joy and thanked him. While leaving, the beggar gave him a very old coin, saying, "Thank you very much. You gave me everything you had. Kindly accept this coin as my humble gift."

When the old man departed, he carelessly glanced at the piece of paper used to wrap the fruit. There he saw an advertisement from an agency dealing with old coins. Any one possessing old coins was invited to visit the agency and receive suitable price for their old coins on the spot. Out of simple curiosity, he carried the coin to the agency, which was quite close to him. He showed the coin gifted by the beggar. The person managing the agency stared at it and exclaimed in excitement, "What a surprise! It is very rare and several centuries old. It is worth a fortune!" He was given a hefty sum of money as the price of the rare coin. Jumping with joy on receiving the unexpected amount of money, he searched 
everywhere to find the old man who gifted him the coin. He wanted to share his joy and the money with the beggar. But he could not find the beggar anywhere. On the way he saw a church. He had abandoned all religious practices for months. But now he entered the church and thanked God for His generous gifts. He started a new life with renewed hope and enthusiasm.

Kindness cannot be given away. It always comes back!

First Simplification

1. A poor young man was helpless, homeless and hopeless

2. A ripe banana was wrapped in an old newspaper.

3. The banana was given to an old beggar.

4. The old beggar gave a coin

5. Advertisement in the newspaper dealt with old coins

6. The young man was given much money for the coin

7. The old man was gone

8. The young man started a new life

Second simplification

\begin{tabular}{|l|l|}
\hline Plot & $\begin{array}{l}\text { a young man, unfortunate, gave a banana to a beggar, given a } \\
\text { coin, sold the coin, rich, started a new happy life }\end{array}$ \\
\hline Setting of time & in the past \\
\hline Setting of place & some place (not stated clearly) \\
\hline Moral value & kindness cannot be given away. It always comes back! \\
\hline
\end{tabular}

\section{Whilst-writing}

a. Making modifications

In this step, I explained how to make modifications and with the students made the possible modifications of the two stories. In fact, there are various ways of making modifications. It can be done to the plot, characters, setting of time and place, wholly or partly. Possible modfications of "Charm Of Charity": 


\begin{tabular}{|c|c|}
\hline The original story & The new story \\
\hline \multicolumn{2}{|l|}{ Plot } \\
\hline a young man & a young woman \\
\hline unfortunate & fortunate, rich, beatiful, etc \\
\hline gave a banana to a beggar, given a coin, & looked down other women \\
\hline sold the coin, rich & robbed, raped \\
\hline started a new happy life & started a miserable life \\
\hline \multicolumn{2}{|l|}{ Setting of Time } \\
\hline In the past & Present time \\
\hline \multicolumn{2}{|l|}{ Setting of Place } \\
\hline In the forest, well & In the city \\
\hline
\end{tabular}

\section{b. Drafting}

The next step is to start writing. Students develop the points above into complete sentences, paragraphs, and complete texts.

\section{c. Revising/Editing}

The last step of writing activity is revising or/and editing. Revising is done to change the plots, characters, ets, while editing is done to edit small problems like mechanics.

\section{d. Post-writing}

As stated earlier in the motivating stage, the end of the project is publishing the students' narrative texts. The texts are compiled into a book of narrative text collection and put in the school library.

\section{Results and discussion}

\section{Writing process}

The result of the observation shows that students were very enthusiastic in completing the task. They were very enthusiastic to follow the presentation about the successful writers. Also, when given the chance to make modifications together in class, students gave various modifications. However, when they had to make modifications individually, some students still could not decide which story to modify. They needed longer time than the others to 
decide what stories to be given 'treatment'. I came to him or her and asked the stories they were already familiar with. When s/he mentioned one, s/he was guided to rewrite the story shortly. When it was done, s/he spent some time to think and give some alternatives in making the modifications. When s/he could find his/her way to make modifications, I moved to other students. Those who did not ask questions usually already had a story in mind. They just continued to make drafts for their stories. This process was done in the second meeting as the first meeting was used to explain the strategy and practiced to discuss and make a new story together in the hope that the students would really understand the strategy before they worked individually. While doing this, I interviewed them by giving questions to find out their attitude towards the strategy. All of them responded positively. They enjoyed the writing activity using this strategy.

The target in the second meeting was that the students could pick up a story, summarized it and had a plan (rough draft) to make modifications to the story and they could continue to develop it at home. In the third meeting, most students already did their job. Third meeting was used to continue their job in class. I circulated and checked one by one to see whether they wrote long enough, made adequate modifications as sometimes students only made minor modifications such as changing the names only. Previously, to make those who had finished busy, students were told to 'decorate' their stories with supporting illustration. They could browse relevant pictures in the internet. In this session I answered questions about grammar, vocabulary, or gave necessary comments on their stories. Sometimes I asked students to give longer description of place or person. For example, when a student wrote"One day, an ugly old woman came to his castle..." I suggested that he should give more description on the 'ugliness' of the old woman. He could add "...she had wrinkles on her forehead, yellow teeth and bad smell!" Or I also gave suggestion to this "He was surprised to see her because she was his lost fiancée, Callista!" He could add "His heart bit 
faster, he held his breath. He could not say anything....she was his lost fiancee, Callista!" In this meeting, students had to submit their works in the form of soft files for feedbacks and deeper observation. In fact some works were rejected as I was convinced that they were just copy pasted from stories in the internet; such as Mouse Deer and Tiger. Another work was also returned, such as The Princesses And the Peanut Seed. The last story was considered still very similar to the original story The Princess And The Pea. In this case, I just showed the original story and let her compare. Therefore she was asked to to revise it and made more changes in some parts of the story. After giving feedbacks, comments, and corrections, the files were returned so that students could revise/edit their work and return it to me as their final work.

\section{Writing products}

There were 22 narrative texts produced by the students (see Table 1). They were varied in terms of length, origin of the story (local or foreign), level of modifications (small parts and big parts of the original story) and complexity of the story. The new stories created by the students were the modifications of the the stories as remembered by the students. However, the stories can be put into four categories. Here are some examples of expected modifications in the project.

\section{Category 1: Modification of some parts of a story.}

One good example of this category is Jasmine and Arabic Shoes. This story is a modification of a story that many that people have known, that is, Aladdin. This story can be found in different languages, different versions, published by different publishers. Student who made modification to this story told that the original story is about a young man called Aladdin. He was a poor young man who lived with his mother. A man who introduced himself as Aladdin's uncle left him in a cave because he didn't want to give an old lamp he had found in 
the cave. By chance he rubbed the lamp with his hands. To his surprise, a genie came out and would grant his wish. In the end, it is known that by the help of the genie of the lamp he became rich and married a king's daughter. In short, the components of the Aladdin's story is Aladdin, as the main character, his mother, his father Mustafa, a man who told Aladdin as his uncle, king, king's daughter, and an old lamp with magical power and genie.

The story of Aladdin was changed by the student in some ways. In her narrative text entitled Jasmine and Arabic Shoes, she admitted that she was inspired with the story of Aladdin. However she created a different character instead. She had Jasmine, a young woman, instead of Aladdin. Jasmine gave her necklace to an old woman. The old woman gave her Arabic shoes. The shoes helped Jasmine. a genie came out of the shoes and would grant her three wishes. The genie made Jasmine rich. The owner of the shoes, Aladdin, came out of the shoes. He was a handsome prince. Later they got married and lived happily ever after.

ARD, the writer of this story explained that she knew the story of Aladdin very well. Since she was interested in the story, she made some modifications to the story. In her story, the main character is not Aladdin, but Jasmine. ARD treated Aladdin as a prince, while in her story, the girl, Jasmine takes the position as Aladdin. Then, instead of using lamp as in the original story, ARD chose shoes as the place where a genie came out (see Appendix 2).

\section{Category 2 : Modification to create a legend of a local place.}

An example for this category is Kalasan Lake, written by DYP. She simply adopted the legend story Toba Lake into her story. She tried to create a story for a small lake near her house. The name of the place, which is located in Kediri, is called Kalasan. Thus the title is Kalasan Lake. In her story, she told about a farmer named Kala. He lived alone in a hut in a farm. One day he took home a golden snail which later on became a beautiful girl. He 
married the girl with one condition that he had to keep the secret that she used to be a snail. Unfortunately, the girl, named San-san was not a good girl. She ate up her father's food. Kala was so angry that he called San-san as the daughter of a snail. Knowing this, her mother was angry and changed the place into a lake. From then on, people called the place as Kalasan Lake. The two stories shared the similar plots. The differences are on the place where the legend is adrresed to and the use of snail instead of fish (see Appendix 3).

\section{Category 3 : Combining more than one stories}

Some students preferred to combine more one stories into a new story. Let's take the story Klotok Mountain written by FAA for example. In Kediri, Klotok is the name of a hill located on the west side of the town. It does not have a popular story like Mount Tangkuban Prahu with its Sangkuriang. FAA was interested to write a story related to the hill. He creatively combined the ideas in stories of Sangkuriang and Jaka Tarub. The story starts with a daughter of king of Daha Kingdom who was drowned in a deep river while she was running away from the enemy of her kingdom. While she was drowning, she promised to herself. If there is a man who could save her, she would marry him. And if there is a woman who could save her, she would take her as a sister. So far this is inspired by Sangkuriang story. Then she was saved by a male dog. As she had promised, she married the dog and had a son, named Krisna. But then the Krisna killed the dog. His mother was angry and the son ran away. On his way in the forest, he saw seven girls (angels) taking a bath in a river. As in Joko Tarub story, he took one of their shawls. One of the girsl could not go back to heaven. Krisna showed up and then he married the girl. One day when cooking, the wife found her shawl that was hidden by Krisna. She took the shawl, wrote a letter saying goodbye to her husband. She put the letter on the cooking pan and left to heaven. Knowing this, Krisna was angry and 
kicked the pan hard. Then the cooking pan turned into Klotok Mountain. The story ends up with the ideas from Sangkuriang (see Appendix 4).

\section{Category 4 : Creating a story of animal's habit}

An example of this modification is the one written by ANG. The title is Why did Female Mosquitoz Bit Human? This story was inspired with the story entitled Why does the Cock Eat the Millipede? ANG told that the original story is about a dragon who borrowed a rooster's golden horn. Guaranteed by a milipede that the horn would be returned, the rooster lent his golden horn to the dragon. Unfortunately, the dragon did not return the golden horn. That's why every morning the rooster looks up in the skies and calls out loud,"Bring back my horns" and eats the millipede he meets.

In her story, ANG writes a story about a fisherman and his wife. One day an old woman gave his wife an apple that made her fainted. A fairy told the man to give her a drop of his blood to his wife to wake her up. But then she ran away and lived with a prince. The fisherman came to the prince's kingdom to pick up his wife. Unfortunately his wife denied him and returned his blood. Suddenly the wife became a mosquito. That's why mosquito always bites to get human blood to return to be a woman again (see Appendix 5).

Table 1. The titles of the stories composed by students

\begin{tabular}{|l|l|l|}
\hline No & Original Story & New Story \\
\hline 1 & Snow White & Fake Snow White \\
\hline 2 & $\begin{array}{l}\text { Beauty And The Beast; The Smartest } \\
\text { Animal; Barbie And The Nutracker. }\end{array}$ & The Buffalo \\
\hline 3 & The Dog And Its Shadow & A Cat And Its Greediness \\
\hline 4 & Pesut Mahakam & Bader Story \\
\hline 5 & Tangkuban Prahu And Jaka Tarub & Klotok Mountain \\
\hline 6 & $\begin{array}{l}\text { Jack The Giant Slayer And The Dwarf } \\
\text { Races }\end{array}$ & $\begin{array}{l}\text { The Brotherhood Of Dwarves And The } \\
\text { Giant }\end{array}$ \\
\hline 7 & Phinoccio & Caroline \\
\hline 8 & Robin Hood & Robin Hood From Java \\
\hline 9 & The Smartest Parrot & The Old Man And His Parrot \\
\hline 10 & Timun Mas & Semangka Mas \\
\hline 11 & Manik Angkeran Story & The Legend Of Malaka Strait \\
\hline 12 & The Legend Of Toba Lake & The Story Of Brantas River \\
\hline
\end{tabular}




\begin{tabular}{|l|l|l|}
\hline 13 & Why Does The Cock Eat The Millipede & $\begin{array}{l}\text { Why Do Female Mosquitoz Bite } \\
\text { Human? }\end{array}$ \\
\hline 14 & Three Pigs And The Wolf & Three Brides And One Groom \\
\hline 15 & Timun Mas & Jasmine And The Witch \\
\hline 16 & The Prince And His Best Friends & The Journey Of The Prince \\
\hline 17 & Little Mermaid And Red Hiding Hood & Little Pink And The Heart Hunter Fox \\
\hline 18 & Legend Of The Toba Lake & Kalasan Lake \\
\hline 19 & The Old Woman And The Sparrow & Joko Who Married A Parrot \\
\hline 20 & The Sleeping Beauty & The Sleeping Baby Ant \\
\hline 21 & Aladdin & Jasmine And Arabic Shoes \\
\hline 22 & The Old Woman And The Sparrow & The Two Twin Girls And The Pigeon \\
\hline
\end{tabular}

The project was aimed at helping students write narrative texts (creating a new story).

The findings above suggest that, students could produce various stories based on the stories that are already there in their memory. Indeed, the stories may be interesting to some people, but uninteresting to other people. At least, they could already produce the stories after long process of writing under the guidance of the teacher as stated in the procedure of the strategy. Thus, instead of practicing the normal procedure to give a writing task, collect the stories, return them for the students to revise the errors or give marks on the stories, as in product approach, teacher tended to practice process approach in this writing project. In this approach, teacher's involvement is essential; giving motivation and helping students in the development process. I believe that motivation is a very important weapon to attack the students' reluctance in completing the writing task. I agree with Montero (2005) that students should not see this writing activity as merely a "school work", but as the skill building that they will possibly need for their future career. That is why, 'talking' about the success of Andrea Hirata and JK Rowling at the beginning of the classroom activity is considered to be helpful in making the students motivated and interested to write. Although I learned that some students already had motivation to write, motivation was still necessary for others. Renandya (2015) suggests that "teachers should look inward, reflect on classroom-specific factors that are within their reach and expertise, and take on a larger responsibility where student motivation is concerned." 
As the students got motivated, a model of narrative text was given. The text was the one the students were already familiar with. Modelling in this is very important for students in writing. It's not only to make students familiar with the text type, but also give the model of the process of simplifying the available text and how to make modifications to the text. In other words, teacher was also demonstrating the strategy. According to Cunningham \& Allington (2007), demonstration usually involves modeling and explaining along with demonstrating the thinking that occurs while reading and writing. Besides, demonstration "gives children the chance to see that skillful strategy use is flexible and always requires thinking, not rote memory of rules". The model of making simplification and graphic organizer makes it easier for the students to comprehend the strategy. This way, I have provided students with the scaffold to help them have foundation before they completed the writing task independently.

Composing the text independently started when a student simplified the text that he planned to modify. Simplification is just like cutting leaves off the trunk. Similarly simplification makes it easy to see the form of the body of the text. Thus it was also easy for the students to choose what parts of the story they planned to modify. Students did not need to find a text from a book or other sources but from their own memory. What they need is to restore the story(ies) they had read or heard before. In other words, the writing process is based on the memory that is already stored in their brains. Thus, the theory of schemata worked here. This is in line with the study by Sun (2014). He concludes that students make great improvement in their English writing after experiencing the schema-oriented instruction. He suggests that it necessary ro students to have rich schemata. This means that those who had 'adequate'schemata would indeed have a chance to write better. Adequate or rich schemata mean that students have already read or heard lots of stories. Thus they have more possible ways of modifying a text. In the process of simplification (pre writing), teacher 
helped the students activate their schemata by giving them sometime to select the stor(y)ies from their brain to modify.

Since the schemata here refers to a story the students have read, there must by sinergy between reading and writing. Pearson (2002) exemplifes that when students are working on writing stories, "there's a natural hook-up to those they read". Pearson argues that the students use the stories they read as models for their writing. Models can be in the form of (1) generic structure, (2) ideas, and (3) language features such as the use of opening sentence "once upon a time" and "they lived happily ever after".

When a story is selected, students write the simplification and then modify it. Sun (2014) mentions that "writing is a cognitive process in which students have to understand what to write and how to write". Since in this project teacher was applying process approach, prior to whilst-writing, students were already helped to activate their schemata of "what to write"by selecting the story to be modified. Students learned "how to write" when teacher was demonstrating how to modify a text. Thus when students had to make modifications, they just restored their experiences in making the modification as they did with the teacher. In short, in the process of writing, students should combine various kinds of schema; linguistic, content, and formal schema (Sun, 2014). This needs creative thinking. Students may coose the same story, but may also have different levels of creativity and imagination. This is as suggested by Lutfiyah (2009) that teacher should provide text model and procedure that help students to develop imagination in generating ideas.

Since this is individual work, the collected stories may be very simple, but may also be very complicated. Also it depends on their motivation. Yulianto (2013) explains that students write narrative texts differently. Students who usually achieve high scores apply the writing stages differently than those who achieve lower scores. The high achievers involve their imagination in the inventing stage. They plan better and draft in order to be able to 
"produce interesting narrative texts while the low achievers intended to just complete the texts easily". Last, the high achievers do the revision and edition more frequently and thus less mistakes are found in the their texts.

\section{CONCLUSION}

It is conclusive that story modification strategy can help write narrative texts successfully. In the project that applied process approach discussed above, many components are involved to succeed in the writing task completion; motivation, scaffolding, reading and writing connection, schemata activation, and creative thinking. It is noted that students may complete their writing task when they have ideas to develop and have the skills to do it. The result of this project indeed gives the evidence that when we provide a writing strategy to complete the task of writing narrative text, students may present to us interesting stories. I admit that the strategy used in this project is not the best one. However, this strategy can be applied by both teachers and students in completing the task of writing narrative text. It is also evident that this strategy is not difficult to apply as students only manipulate ideas they have in their memory. In short, writing narrative text is just like 'cooking' the ingredients that are already stored in our minds. In line with Sun (2014), the results of the project give implications that to succeed in teaching writing, a teacher should assign his/her students to read a lot to enrich the schemata and improve their competence to process all the schemata in order to create a qualified composition.

To end this paper let me quote the principle from our father of education; Momong, Among, Ngemong (Tauchid, et. al: 1961: 13). Momong, Among, Ngemong that is known as Amongsystem is "menyokong chodrat alamnya anak-anak yang kita didik, agar dapat mengembangkan hidupnya lahir dan batin menurut chodratnya sendiri-sendiri" (supporting the natures of our students, so they can develop their lives spiritually and physically based on 
their own natures). This gives a deep message to us that teacher should not leave students in the process of finding the knowledge alone. Instead, a teacher should be available beside his students to make sure that they are on the right track in finding knowledge.

\section{About the writer}

Bambang Yulianto is an English teacher at SMAN 1 Kediri, East Java. He was born in Kediri in 1971. He earned his undergraduate in English Department of IKIP Malang in 1996 and graduate degree in Universitas Negeri Malang in 2013.

\section{References}

Allington. R.L. \& Cunningham. P.M. (2010). Children Benefit from Modeling,Demonstration, and Explanation. Pearson Allyn Bacon Prentice Hall Retrived from $\quad$ http://www.education.com/reference/article/children-benefitmodeling-demonstration/

Arini. YD \& Kurniawati. C. (2014). Buku PR Bahasa Inggris untuk SMA/MA. Klaten. Intan Pariwara.

Brown, H.D. (2007). Teaching by Principles: An Interactive Approach to Language Pedagogy. White Plains, NJ: Pearson Education

Depdiknas. (2004). Kurikulum Berbasis Kompetensi (Competence Based Curriculum). Jakarta: Depdiknas

Lutfiyah, L. (2009). Utilizing Photographs to Improve Writing Ability of the Second Year Students of Madrasah Tsanawiyah Negeri Mojorejo Blitar. Unpublished Thesis. Malang: Graduate Program in English, State University of Malang 
Montero, A. (2005). What A Feeling! Motivating Efl Students Through Colaborative Writing With Poems. English Teaching Forum, 43 (3): 36 - 39

Pearson, D. (2002). Thinking About the Reading/Writing Connection with David Pearson. National Writing Project.

Retrieved from http://www.nwp.org/cs/public/print/resource/329

Renandya, W.A. (2015). L2 motivation: Whose responsibility is it? English Language Teaching, 27(4), 177-189.

Sellers. D. (Producer), \& Santostefano. D (Director). (2008). Another Cinderella Story (Motion Picture). United States: Dylan Sellers Production

Sun, F. (2014). The Application of Schema Theory in Teaching College English Writing. Theory and Practice in Language Studies, Vol. 4, No. 7, pp. 1476-1482. Retrieved from http://www.academypublication.com/issues/past/tpls/vol04/07/23.pdf

Tauchid, et. al. (1961). Karya Ki Hajar Dewantara. Taman Siswa, Jogyakarta.

Montero, A. (2005). What A Feeling! Motivating Efl Students Through Colaborative Writing With Poems. English Teaching Forum, 43 (3): 36 - 39

Wikipedia. (2016). https://en.wikipedia.org/wiki/A_Cinderella_Story

Tauchid, et. al. (1961). Karya Ki Hajar Dewantara. Jogyakarta: Taman Siswa

Yulianto, B. (2013). The Strategies Used by the High Achievers and Low Achievers of the Tenth Graders of SMAN 1 Kediri in Writing Narrative Texts. Thesis. The English Language Education, Graduate Program, State University of Malang. 